\title{
FABRICATION OF PERIODIC MICRO-STRUCTURES BY HOLOGRAPHIC LITHOGRAPHY
}

\author{
E. Stankevičius ${ }^{\text {a }}$, M. Gedvilas ${ }^{\text {a }}$, B. Voisiat ${ }^{\text {a }}$, M. Malinauskas ${ }^{\text {b }}$, and G. Račiukaitis ${ }^{\text {a }}$ \\ ${ }^{a}$ Center for Physical Sciences and Technology, Savanoriu 231, LT-02300 Vilnius, Lithuania \\ ${ }^{\mathrm{b}}$ Laser Research Center, Vilnius University, Sauletekio 10, LT-10223 Vilnius, Lithuania \\ E-mail: evaldas.stankevicius@ar.fi.lt
}

Received 27 May 2013; revised 29 September 2013; accepted 4 December 2013

\begin{abstract}
The principles of the holographic lithography technique are reviewed, and the ability in the formation of structures with different periods by the holographic lithography technique in SZ2080 is demonstrated. The influence of laser exposure, phase shift between interfering laser beams, and the used laser wavelength on the structures fabricated by the four-beam interference technique has been studied. It is shown that by using the interfering beams with a different phase is it possible to reduce the period of the structure $\sqrt{2}$ times compared to the four interfering beams of the same phase. Fabrication of micro-structures by the holographic lithography technique can be realized via multi-photon and single-photon polymerization processes. The structures created by these two techniques are compared. Finally, in the experiments with the five-beam interference, the doubleperiod effect was observed by adding the zero-order beam with a low intensity. The fabricated periodic microstructures have the potential to be used as a scaffold for cell growth and micro-optics.
\end{abstract}

Keywords: holographic lithography, four-beam interference, SZ2080, periodic micro-structures, multi-photon polymerization, double-period effect

PACS: 02.50.Tt, 82.35.-x, 85.40.Hp

\section{Introduction}

The fabrication technique based on the optical holographic lithography (HL) [1-3] is among the most practical and elegant approaches to the fabrication of extended periodic micro- and nano-structures [4]. HL is based on the multi-beam interference phenomenon. By recording the multi-beam interference pattern into photoresist it is possible to fabricate $1 \mathrm{D}, 2 \mathrm{D}$, and $3 \mathrm{D}$ periodic structures by a single laser exposure. Depending on laser wavelength, exposure can be achieved via linear [5] or nonlinear absorption [ 6 ]. HL allows fabricating periodic structures over a large area relatively fast and that makes this technique attractive and promising for mass-fabrication of functional devices such as photonic crystals [7-10] or scaffolds [11, 12]. HL has certain advantages over the direct laser writing
(DLW) technique [13] due to the rapid fabrication of periodic structures. The basic principles of DLW and HL techniques are shown in Fig. 1. In the DLW technique, the photo-polymerization process is induced in the focal region of a tightly focused laser beam. By translation of the focal spot in the photosensitive material, any $3 \mathrm{D}$ shapes can be recorded. The laser wavelength is selected in the transmission window of the polymer. Therefore, two- or even three-photon processes are involved. For this reason, high laser intensities are required. Therefore, femtosecond lasers are usually used for multi-photon laser polymerization. By the DLW technique only one voxel (volumetric pixel) is fabricated by a single laser exposure in the focal area of the objective, whereas in the HL technique a periodic structure is formed in the whole area irradiated with the overlapping laser beams using a single laser 


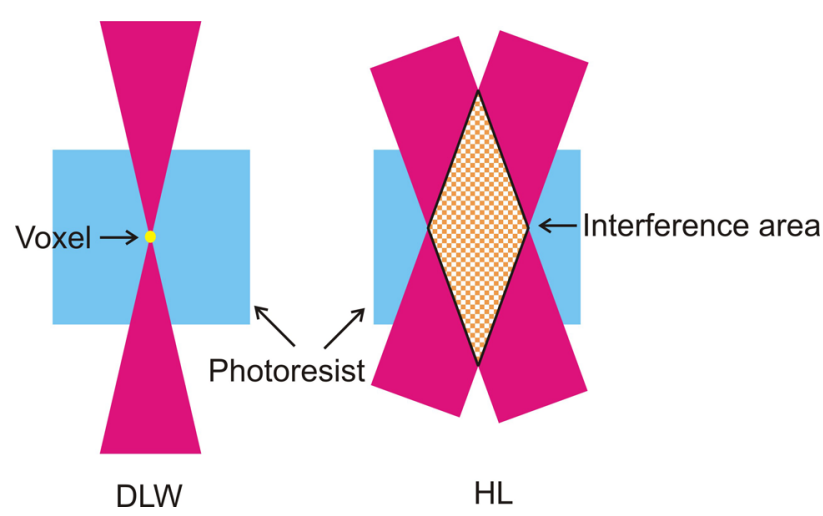

Fig. 1. Principles of direct laser writing and holographic lithography techniques.

exposure. The HL technique demonstrates rapid fabrication of periodic structures, but not every desired shape of the structure can be fabricated by HL as in case of DLW. The HL technique enables fabricating only periodic structures which correspond to the beam interference pattern.

\section{Principles of the holographic lithography technique}

Interference of electro-magnetic waves appears when at least two coherent beams propagating at a certain angle to each other interact. In a general case, the intensity profile in the interference area can be expressed by the equation [14]:

$$
I(\overrightarrow{\mathbf{r}}) \propto\left\langle\left(\sum_{i=1}^{N} \overrightarrow{\mathbf{E}}_{i}(\overrightarrow{\mathbf{r}}, t)\right)^{2}\right\rangle,
$$

where $\overrightarrow{\mathbf{E}}_{i}$ is the electrical field of the $i$ beam, $\overrightarrow{\mathbf{r}}$ is the coordinate vector, $i$ is the index of interfering beams, $N$ is the number of the beams, $t$ is time, brackets denote averaging in time at least for one period of electro-magnetic field oscillations. The electrical field of the $i$ wave can be expressed as follows:

$$
\overrightarrow{\mathbf{E}}_{i}=\overrightarrow{\mathbf{E}}_{0 i} \cos \left(\overrightarrow{\mathbf{k}}_{i} \cdot \overrightarrow{\mathbf{r}}-\omega t+\varphi_{i}\right),
$$

where $\left|\overrightarrow{\mathbf{E}}_{0 i}\right|$ is the electrical field amplitude of the $i$ wave, $\left|\overrightarrow{\mathbf{k}}_{i}\right|=2 \pi / \lambda$ is the wave vector of the $i$ wave, $\lambda$ is the wavelength of radiation, $\omega$ is the frequency of radiation, $\varphi_{i}$ is the phase of the $i$ wave. When frequencies of all laser beams are the same, Eqs. (1) and (2) can be simplified as follows [15]:

$$
\begin{aligned}
& I(\mathbf{r}) \propto \frac{1}{2} \sum_{i=1}^{N}\left|\overrightarrow{\mathbf{E}}_{0 i}\right|^{2}+ \\
& +\sum_{j<i}^{N} \sum_{i=1}^{N} \overrightarrow{\mathbf{E}}_{0 i} \cdot \overrightarrow{\mathbf{E}}_{0 j} \cos \left(\overrightarrow{\mathbf{k}}_{i} \cdot \overrightarrow{\mathbf{r}}-\overrightarrow{\mathbf{k}}_{j} \cdot \overrightarrow{\mathbf{r}}+\varphi_{i}-\varphi_{j}\right) .
\end{aligned}
$$

The periodical intensity field is formed, and the period depends on the incident angle between the beams and the wavelength of laser radiation. Dependences of the intensity field period on the incident angle between the beams and the wavelength when two, three, four, five, and six beams interfere are shown in Table 1. The shape of the pattern is affected by the number of beams and the phase dif-

Table 1. Relation between the period of interference patterns, angle of incident for interfering beams and wavelength of light depending on the number of symmetrically arranged beams. $\theta$ is the angle between a beam and optical axis, and $\lambda$ is the wavelength of interfering beams.

\begin{tabular}{c|c}
\hline $\begin{array}{c}\text { Number of inter- } \\
\text { fering beams }\end{array}$ & Period of interference pattern \\
\hline 2 & $\Lambda_{2}=\frac{\lambda}{2 \sin \theta}[14]$ \\
\hline 3 & $\Lambda_{3}=\frac{\lambda}{\sqrt{3} \sin \theta}[32]$ \\
\hline 4 & $\Lambda_{4}=\frac{\lambda}{\sqrt{2} \sin \theta}[33$
\end{tabular}

ference between them. The periodical intensity distribution patterns of several set-ups of symmetrically arranged beams calculated by using Eq. (3) are given in Fig. 2.

\section{Experimental set-ups of holographic lithography and their features}

There are several methods of beam collection into the sample. The beams for holography arrangements are split and can be collected by using the beamsplitters (Fig. 3(a)) 16, 17, the diffractive 
(a)

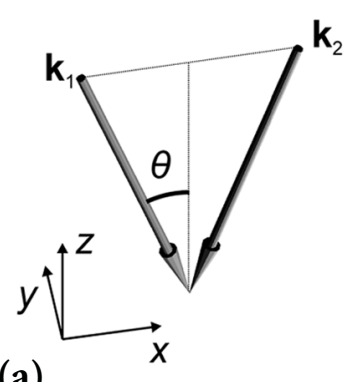

(c)

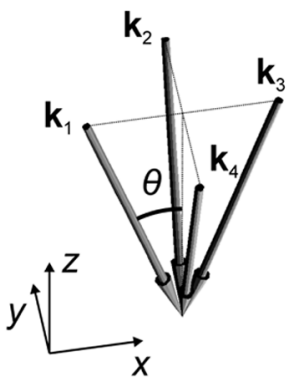

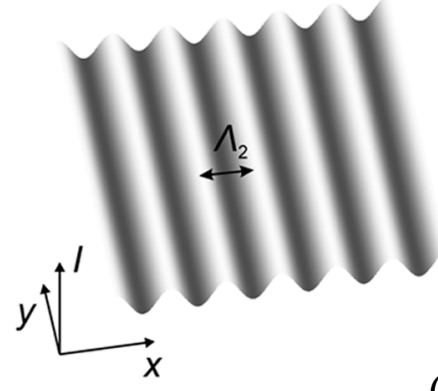

(b)
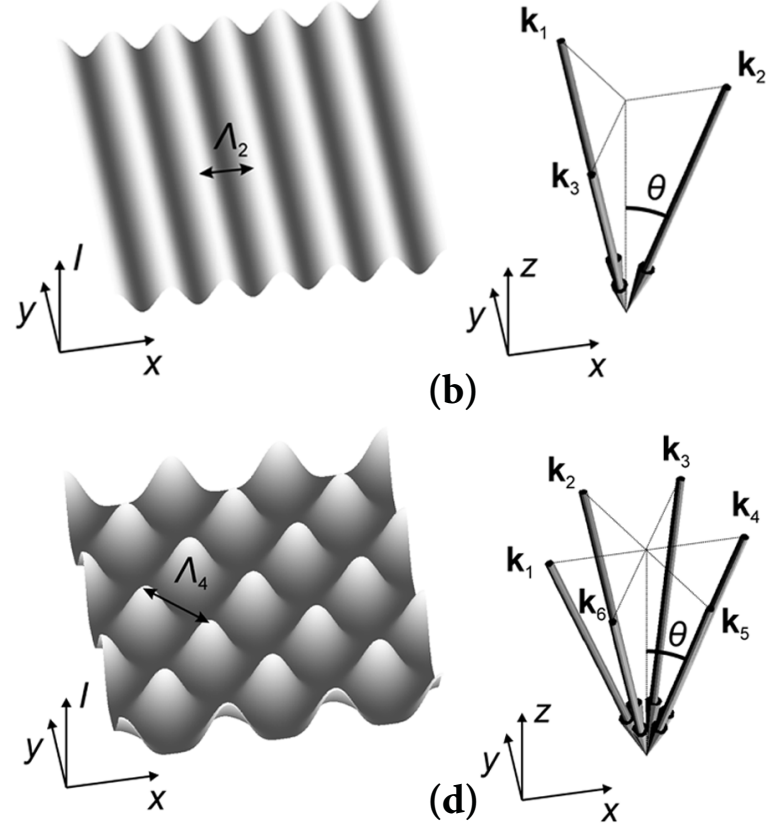
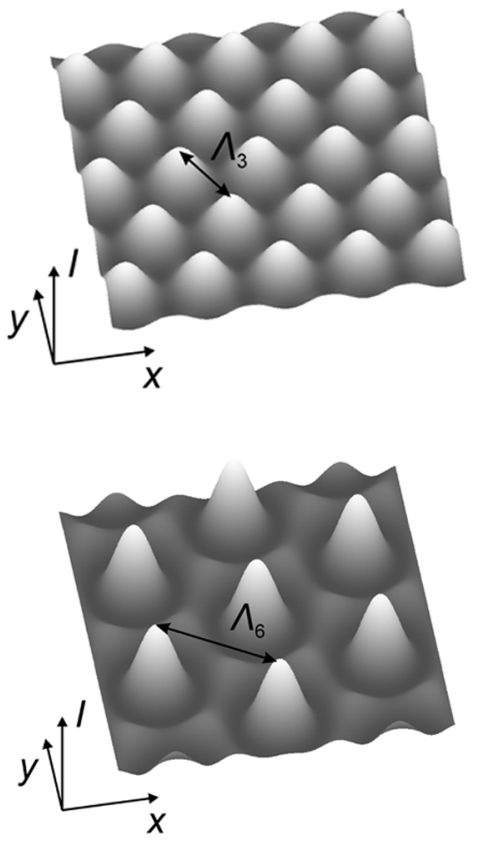

Fig. 2. Wave vectors of the interfering beams and intensity distribution for the interference field of symmetrically arranged laser beams calculated by using Eq. (3): (a) two, (b) three, (c) four, (d) six beams. $x y z$ denotes a coordinate system, $I$ is the intensity distribution in the interference pattern, $\overrightarrow{\mathbf{k}}_{1}, \overrightarrow{\mathbf{k}}_{2}, \overrightarrow{\mathbf{k}}_{3}, \overrightarrow{\mathbf{k}}_{4}, \overrightarrow{\mathbf{k}}_{5}$, and $\mathbf{k}_{6}$ are the wave vectors of the interfering beams, $\theta$ is the angle between the beam and $z$ direction.

optical element (DOE) with a confocal focusing system (Fig. 3(b)) [18, 19], the liquid-crystal spatial light modulator (LC-SLM) (Fig. 3(c)) [20], the topcut prism (Fig. 3(d)) [21], etc.

Experimental set-ups with LC-SLM are easily tunable and can dynamically reconfigure the number of interfering beams and their location on the liquid crystal but these set-ups are very sensitive to temperature and for this reason only low energy pulses are acceptable in this set-up. The high energy pulses are suitable for other types of experimental set-ups (with a DOE, beamsplitter, or top-cut prism).

Experimental set-ups with a DOE have several advantages over experimental systems with beamsplitters or the top-cut prism. The experimental set-up with a DOE has the ability to change the angle between interfering beams by using lenses with different focal lengths in the image translation part (4F imaging). In the experimental set-up with the top-cut prism, the interference angle between interfering beams remains stationary, and fabrication of the periodic structure with a fixed period is only possible. This period depends on the geometry of the prism.

The main advantage of the experimental set-up with a DOE over that with the beamsplitter is that a
DOE produces mutually coherent laser beams and these beams arrive to the beam intersection area as nearly plane waves with a vanishing optical path difference. The coherence and zero-time delay are maintained across the entire cross-section of the tilted pulses despite their different propagation directions, and the interference occurs in the entire spot area due to DOE ability to tilt short pulses [22, 23. The wavefront of the beams is not tilted after passing the beamsplitter. Therefore, temporal and spatial overlap of laser pulses occurs only in a limited region, not in the entire spot area [24].

In this paper we will consider the experimental set-up of HL with a DOE. All structures shown below were fabricated by using the experimental set-up which contains a femtosecond laser Pharos (1030 and $515 \mathrm{~nm}, \sim 290 \mathrm{fs}, 6 \mathrm{~W}, 600 \mathrm{kHz}$, Light Conversion Ltd.), a diffractive optical element (DOE, separation angle between beams for the first harmonics $2.8 \mathrm{deg}$ and for the second harmonics $1.4 \mathrm{deg}$, HoloOR Ltd.), two lenses (L1 and L2), a diaphragm (D), and the positioning system XYZ (Fig. 3(b)). The laser beam in the experimental system was controlled with the electro-optical shutter. A DOE was used to split the laser beam into several beams. The diaphragm was used to block 


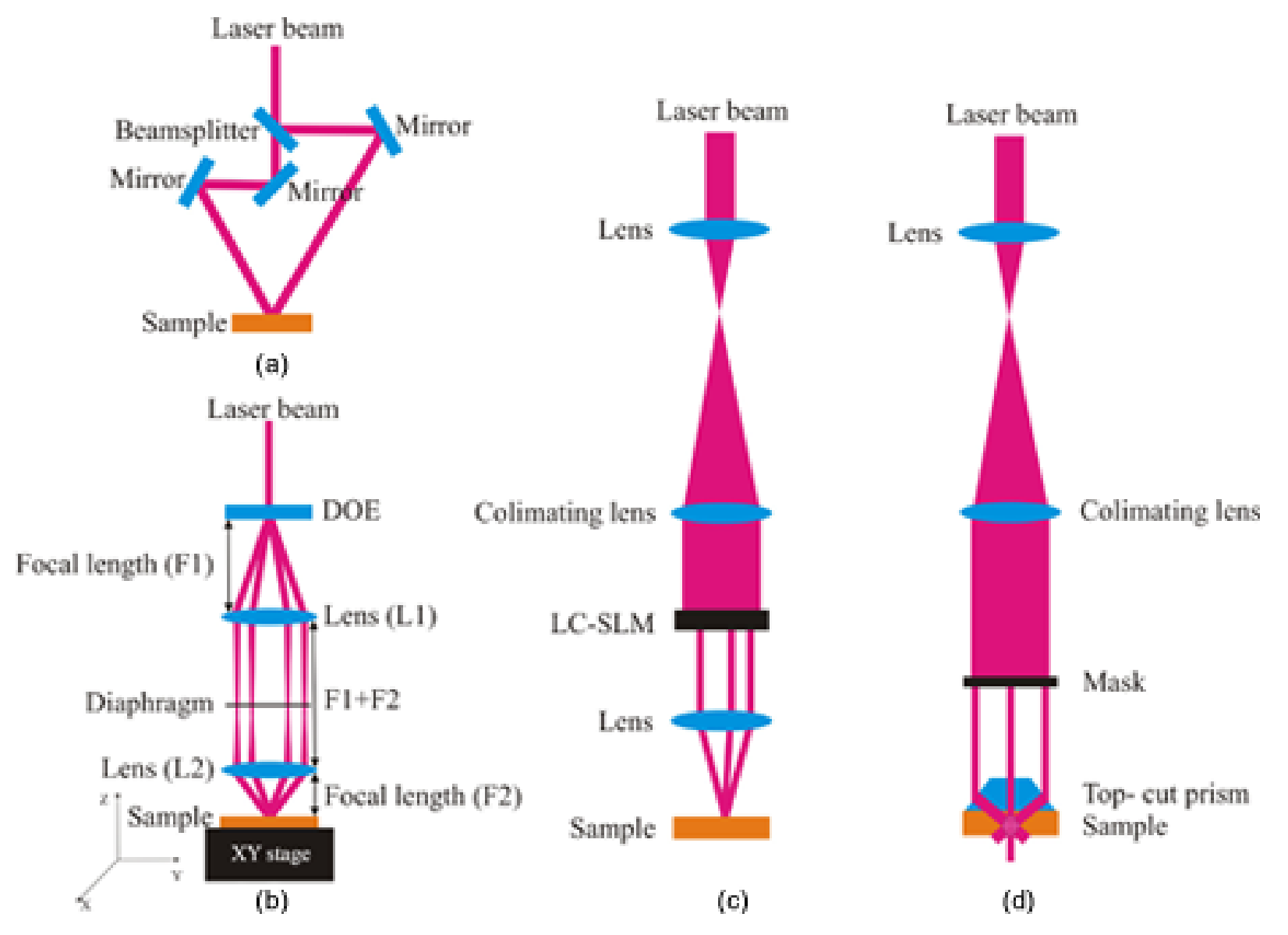

Fig. 3. Beam collection methods by using: (a) beamsplitters, (b) DOE, (c) LC-SLM, (d) top-cut prism.

undesirable beams that appear after splitting the laser beam with the DOE. The energy of the laser was tuned directly from the laser control board. The commercial hybrid organic-inorganic Zr-containing negative photoresist SZ2080 (chemical formula $\mathrm{C}_{4} \mathrm{H}_{12} \mathrm{SiZrO}_{2}$ ) [25] (FORTH, Greece) with the photo-initiator 4,4'-bis(dimethylamino)benzophenone (BIS) concentration by w. t. equal to $0.5 \%$ or $1 \%$ (in the second harmonic experiments) and $2 \%$ (in fundamental harmonic experiments) was used. This material was chosen due to its low shrinkage, mechanical stability, and possibility to photosensitize it optimally for the used irradiation.

\section{Structures fabricated by holographic}

\section{lithography with a diffractive optical element} and four-beam interference

The shape of structures fabricated by HL depends on the intensity distribution of the interference field. By using HL it is possible to fabricate only periodic structures. The period of structures fabri- cated by HL depends on the angle between interfering beams and the wavelength of used beams $(\sim \lambda / \sin \theta)$. The relation between the period of the interference pattern and the number of the interfering beams is shown in Table 1. An example of structures fabricated by the four-beam interference with a different period (12 and $60 \mu \mathrm{m}$ ) in SZ2080 material is shown in Fig. 4 .

By fabricating periodical structures, besides their period the shape of pillars and the free space between the pillars (for cell growth, for example) are also important. This space can be controlled by using a different laser wavelength or managing the laser irradiation dose (the product of the exposure time and the average laser power). Structures fabricated using different wavelengths (fundamental and second harmonics of the laser) are compared in Fig. 5. The structures fabricated by using the second harmonics ( $515 \mathrm{~nm}$, close to the maximum absorption of the used photo-initiator) have thicker pillars than by using the fundamental harmonics $(1030 \mathrm{~nm})$ (Fig. 5) despite that laser irradiation was 


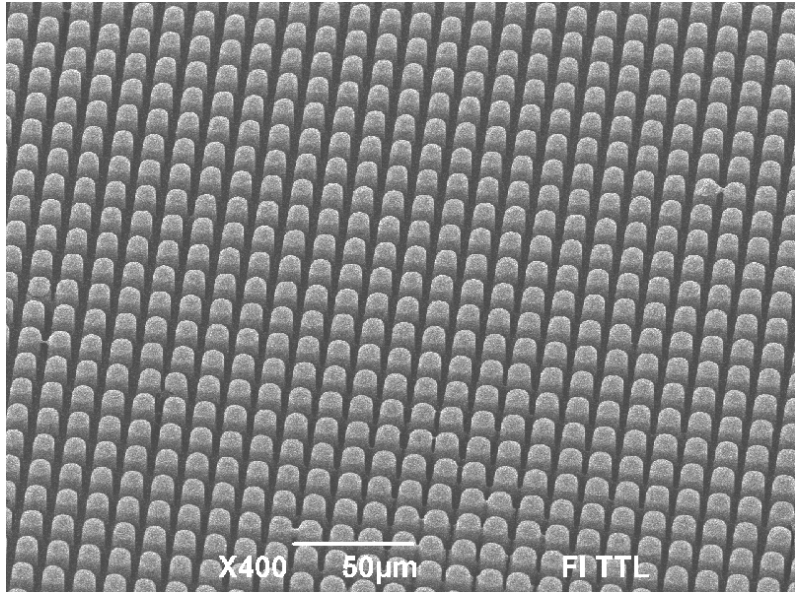

(a)

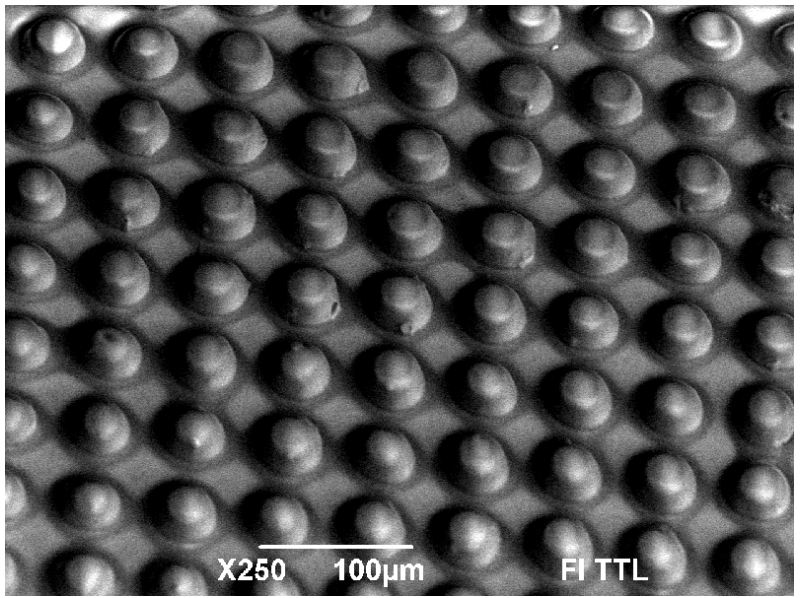

(b)

Fig. 4. Periodic structures fabricated by the four-beam interference in SZ2080 material with a different period: (a) $12 \mu \mathrm{m}$ (angle $\sim 1.74 \mathrm{deg}$ ) and (b) $60 \mu \mathrm{m}$ (angle $\sim 0.35 \mathrm{deg}$ ). Laser parameters: wavelength $515 \mathrm{~nm}$, exposure time $1 \mathrm{~min}$, pulse energy (a) $6 \mu \mathrm{J}$ and (b) $21 \mu \mathrm{J}$. SEM images of the structures are tilted by $34 \mathrm{deg}$.

155 times larger, pulse energy was 51 times higher, and concentration of the photo-initiator was 4 times higher in experiments with the fundamental harmonics than in experiments with the second harmonics. The reason for this effect is that the maximum in the absorption spectrum of the used material (SZ2080 with BIS photoinitiator in a solid state) is at $\sim 470 \mathrm{~nm}$ [26] close to the wavelength of the second harmonics of the used laser $(515 \mathrm{~nm})$. It means that by using the second harmonics, the single-photon polymerization took place, and by using the fundamental harmonics $(1030 \mathrm{~nm})$ the multi-photon polymerization took place. The multi-photon polymerization process required high laser intensities, and the sharpening of the structure compared with the intensity distribution was observed. Moreover, by using this technique it is possible to fabricate not only pillar arrays but also more complex structures such as micro-tubes arrays [27].

Structures fabricated by the four-beam interference with a different exposure time and the

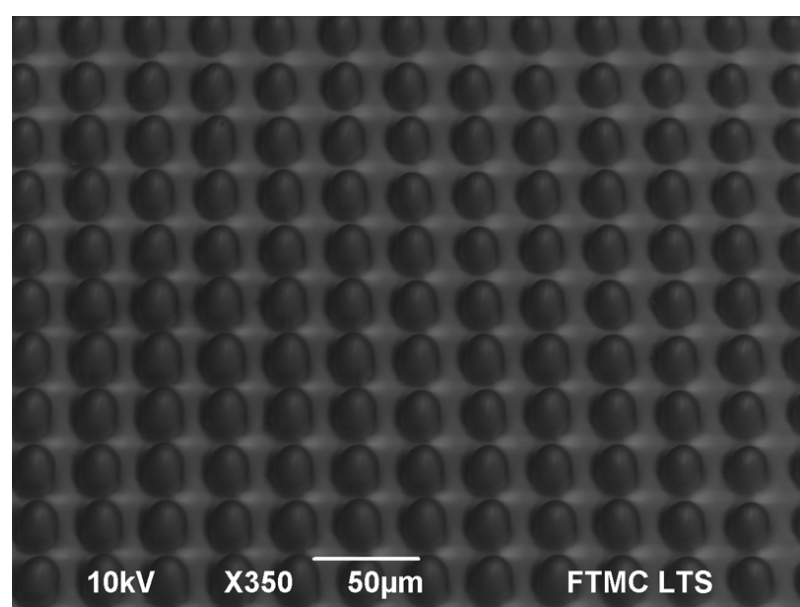

(a)

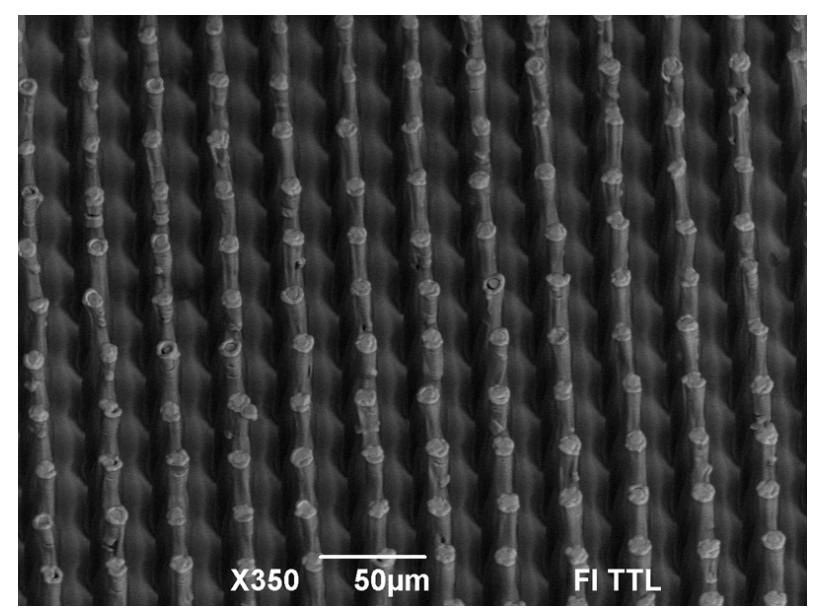

(b)

Fig. 5. Pillar arrays of SZ2080 fabricated by using: (a) the second harmonics $(515 \mathrm{~nm})$, average laser power $270 \mathrm{~mW}$, repetition rate $100 \mathrm{kHz}$, peak pulse intensity $\sim 4.3 \mathrm{GW} / \mathrm{cm}^{2}$, exposure time $5 \mathrm{~s}$, and BIS concentration $0.5 \%$ by w. $\mathrm{t}$., (b) the fundamental harmonics $(1030 \mathrm{~nm})$, average laser power $700 \mathrm{~mW}$, repetition rate $5 \mathrm{kHz}$, peak pulse intensity $\sim 0.22 \mathrm{TW} / \mathrm{cm}^{2}$, exposure time $5 \mathrm{~min}$, and BIS concentration $2 \%$ by w. t. SEM images of the structures are tilted by $34 \mathrm{deg}$. 
second harmonics $(515 \mathrm{~nm})$ are shown in Fig. 6 . When the exposure time is too short $(0.1 \mathrm{~s})$ and the irradiation dose $(\sim 16.5 \mathrm{~mW} \cdot \mathrm{s})$ is close to the photo-polymerization threshold, the fabricated structures are too weak and they do not survive the development process and collapse (Fig. $6(\mathrm{a})$ ) [28]. By increasing the laser irradiation dose, the photo-modification regions (blue area in Fig. 6) and the polymer chain length also increase and the structures become stronger and they can survive the development process (Fig. 6(b), exposure time $0.5 \mathrm{~s}$ and irradiation dose $\sim 82.5 \mathrm{~mW} \cdot \mathrm{s})$. The increased laser irradiation dose initiates the photo-polymerization reactions over the larger area, and when photo-modified regions are close to each other the self-polymerization effect initiated by radicals diffusion [29] starts to act and in such a way the "comb" structure is formed (Fig. 6(c)). The "comb" structure was formed with/at the exposure time of $1 \mathrm{~s}$ and the irradiation dose of $\sim 165 \mathrm{~mW} \cdot \mathrm{s}$.

The shape of the fabricated periodic structure can be managed by changing the phase or the polarization of interfering beams. The four-beam (a)
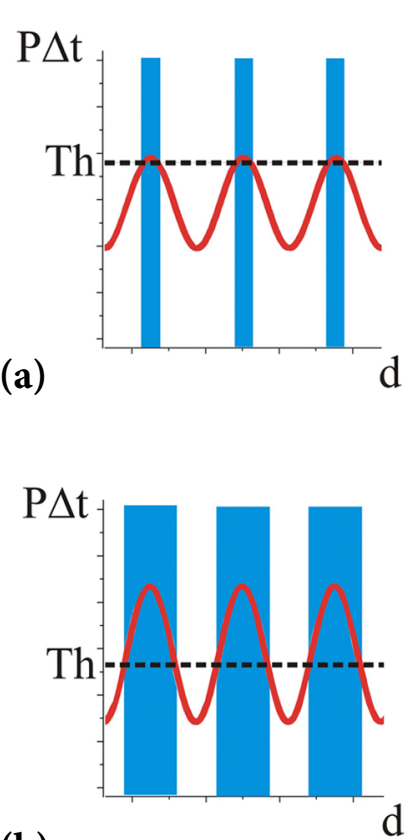

(b)

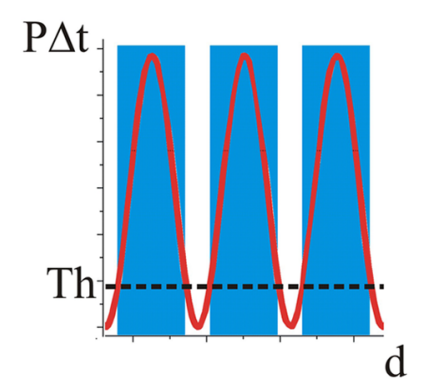

$\Delta \mathrm{t}=\mathrm{t}_{1}$

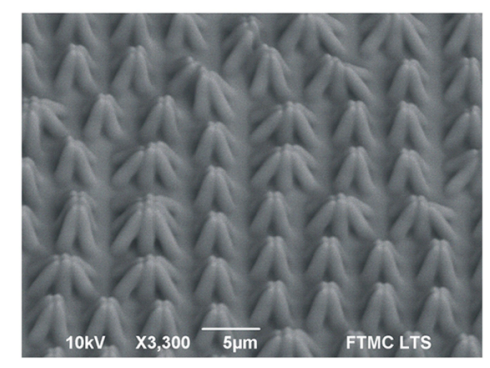

$\Delta \mathrm{t}=\mathrm{t}_{2}$

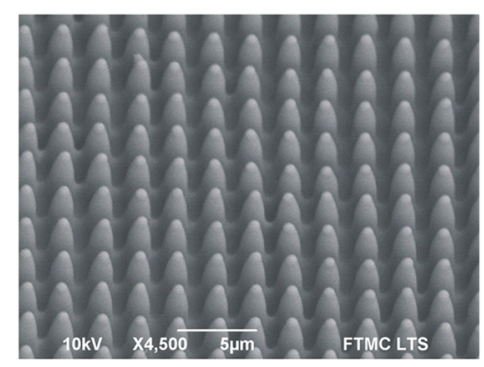

$\Delta \mathrm{t}=\mathrm{t}_{3}$

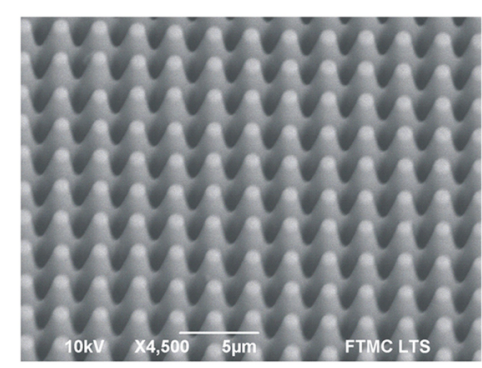

(c)

Fig. 6. Structures fabricated in SZ2080 with BIS concentration of $0.5 \%$ by w. t. by the four-beam interference technique with different laser exposure times: (a) $t_{1}=0.1 \mathrm{~s}$, (b) $t_{2}=0.5 \mathrm{~s}$, (c) $t_{3}=1 \mathrm{~s}$. Blue regions are photo-modified areas, red solid line is the periodic laser intensity distribution, Th is the threshold of polymerization, $\mathrm{d}$ is the transverse spatial coordinate, $\mathrm{P} \Delta \mathrm{t}$ is the laser dose. Laser parameters of fabricated structures on the right side: $515 \mathrm{~nm}, 165 \mathrm{~mW}, 100 \mathrm{kHz}, \sim 24 \mathrm{GW} / \mathrm{cm}^{2}$; the period of interference pattern $2.5 \mu \mathrm{m}$. SEM images of the structures are tilted by $34 \mathrm{deg}$. 
interference pattern when the phase of two opposite interfering beams ( $\mathbf{k}_{1}$ and $\mathbf{k}_{3}$ in Fig. 2(c)) is shifted by $3 / 8 \pi$ in respect of the other two beams $\left(\mathbf{k}_{2}\right.$ and $\mathbf{k}_{4}$ in Fig. 2(c)) is shown in Fig. 7(a). In Fig. $\mathbb{F}(\mathrm{b})$ the structure fabricated by the holographic lithography technique using the twobeam phase shift is shown. This phase difference results in the appearance of the additional intensity maxima. The maximum surrounded by four initial maxima is weaker, but its intensity is still sufficient to initiate the polymerization process [30]. In addition to the weak maximum (small pillar), links between all pillars are polymerized, which makes the structure stable even when separated from a substrate (free-standing).

More four-beam interference patterns simulated with different phase shifts are depicted in Fig. 8 in order to show flexibility of patterning by the HL method.

When the phase of two opposite beams is shifted by $\pi / 2$ in respect of the other two beams, the period of an intenference pattern is reduced by $\sqrt{2}$ (Fig. 8(c)) [31]. The fabricated structure with the reduced period is shown in Fig. 9. In principle, it is possible to control this intensity distribution not only by changing the phases of interfering beams but also by changing the polarization of interfering beams. When the polarization of two opposite beams $\left(\mathbf{k}_{1}\right.$ and $\mathbf{k}_{3}$

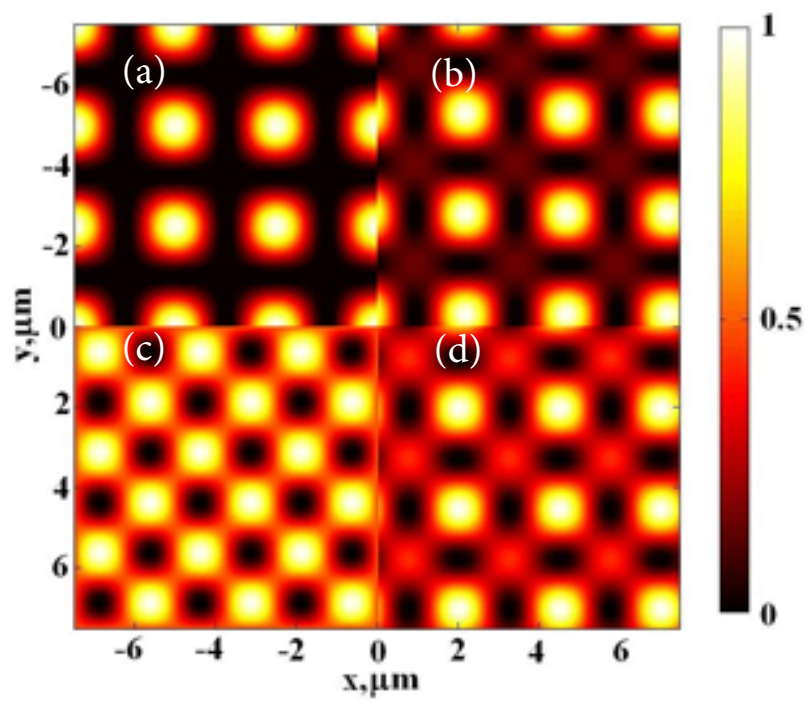

Fig. 8. Four-beam interference pattern when the phase shift of two opposite beams of other two beams is: (a) 0 , (b) $\pi / 4$, (c) $\pi / 2$, (d) $3 / 8 \pi$.

(Fig. 2(c)) is the same and the polarization vector of other two beams is rotated by $90 \mathrm{deg}$ (beam $\mathbf{k}_{2}$ (Fig. 2(c)) and -90 deg (beam $\mathbf{k}_{4}$ (Fig. 2(c)) in respect of the polarization vector of beams $\mathbf{k}_{1}$ and $\mathbf{k}_{3}$, the period of the interference pattern of such beams is also reduced by $\sqrt{2}$. The polarization control approach was not realized in this research.

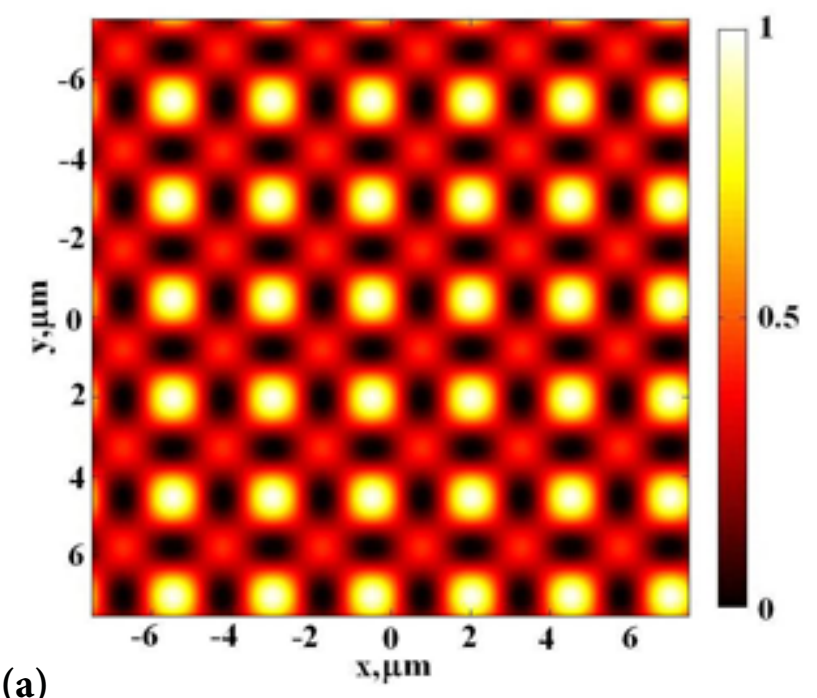

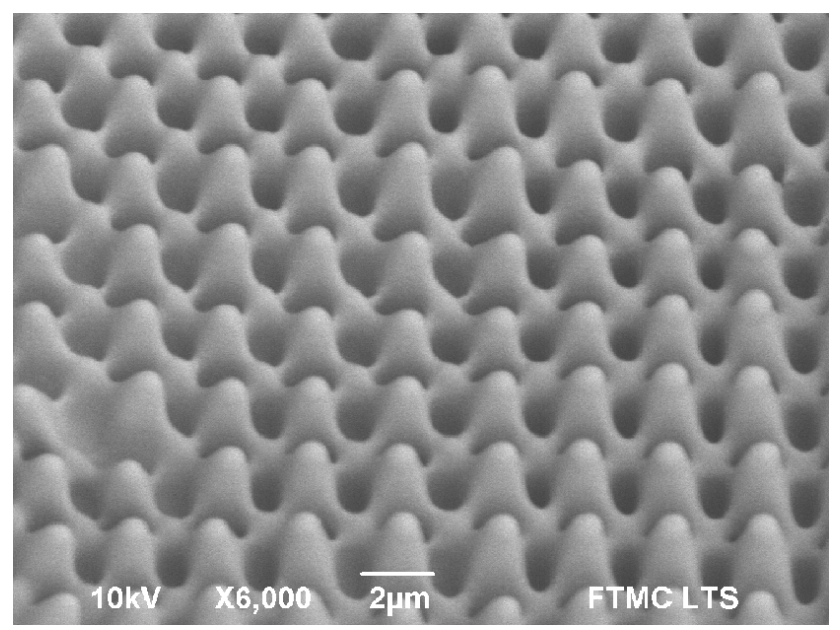

(b)

Fig. 7. (a) Theoretically calculated interference pattern of four beams when the phase of two opposite beams is shifted by $3 / 8 \pi$. (b) Fabricated periodic structure in SZ2080 with BIS concentration of $0.5 \%$ by w. t. with the phase shift equal to $3 / 8 \pi$. The structure was fabricated by using such laser parameters: wavelength 515 nm, average power $165 \mathrm{~mW}$, repetition rate $100 \mathrm{kHz}$, peak pulse intensity $24 \mathrm{GW} / \mathrm{cm}^{2}$, exposure time $1 \mathrm{~s}$. SEM image of the structure is tilted by $34 \mathrm{deg}$. 


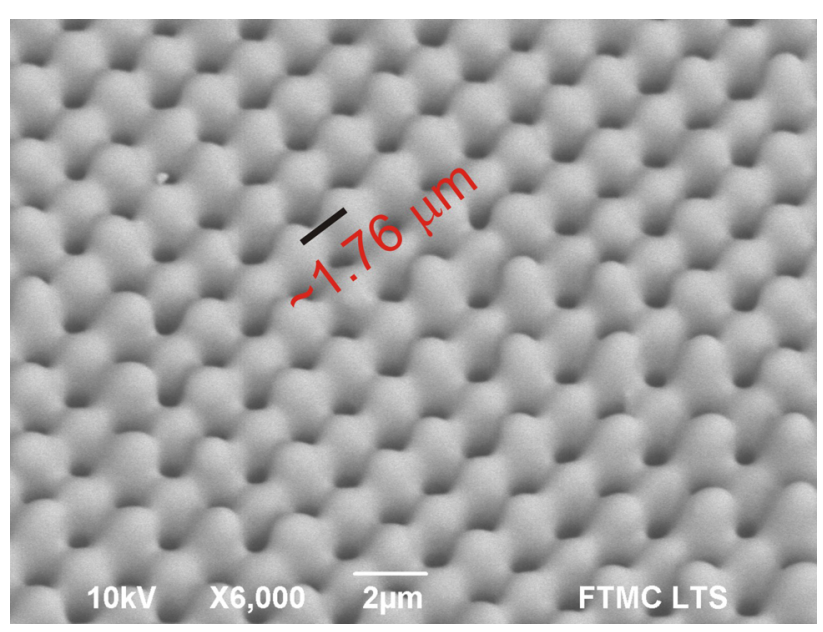

Fig. 9. Structure fabricated by the phase-shift method in SZ2080 with BIS concentration of $0.5 \%$ by w. $t$. The period of fabricated structures is $\sim 1.76 \mu \mathrm{m}$. The structure was fabricated by using such laser parameters: wavelength $515 \mathrm{~nm}$, average power $230 \mathrm{~mW}$, repetition rate $100 \mathrm{kHz}$, peak pulse intensity $\sim 33 \mathrm{GW} / \mathrm{cm}^{2}$, exposure time $1 \mathrm{~s}$. SEM image of the structure is tilted by $34 \mathrm{deg}$.

\section{Structures fabricated by holographic lithography with a diffractive optical element and five-beam interference}

By adding the fifth central beam (zero order) with a small intensity (in our case $\sim 7$ times smaller than the intensity in the first order beam), the doubleperiod effect in $x$ and $y$ directions (Fig. 10(a)) is observed in the intensity distribution. In our case, the intensity of every second interference maximum was lower by about $30 \%$ (Fig. 10(b)). Actually, by adding the fifth beam (zero-order), it is possible to fabricate 3D structures but only when the angle between interfering beams and the zero-order beam is quite large (more than $10 \mathrm{deg}$ ). At small angles (less than $10 \mathrm{deg}$ ) the period in $\mathrm{z}$ direction is very large and can be 10 times larger than the period in $x$ and $y$ directions. The fabricated structures in SZ2080 photopolymer with the five-beam interference pattern are shown in Fig. 11. The structures were fabricated with the laser of the same parameters (average power $\sim 400 \mathrm{~mW}$, repetition rate $5 \mathrm{kHz}$, peak pulse intensity $\sim 0.13 \mathrm{TW} / \mathrm{cm}^{2}$, exposure time $25 \mathrm{~s}$, laser wavelength $1030 \mathrm{~nm}$ ), and concentration of the photo-initiator BIS concentration was $\sim 2 \%$ w. t. Only the thickness of the photopolymer in this case was different: $\sim 25 \mu \mathrm{m}$ in Fig. 11(a) and $\sim 60 \mu \mathrm{m}$ in Fig. 11(b). As can be seen from Fig. 11, the $2 \mathrm{D}$ structures were fabricated by using the five-beam interference because the period in $z$ direction under used experimental conditions $(\sim 3.45 \mathrm{~mm})$ was larger than the thickness of the used photopolymer. Since every second maximum of the used five-beam interference pattern is lower, the diameter of every second fabricated pillar is also smaller. The pillars fabricated by using lower intensity in the thinner photopolymer were strong enough to survive the development process, and they were almost twice thinner than the pillars fabricated using higher intensity. The pillars fabricated using lower intensity in the thicker photopolymer were not able to survive the development process,

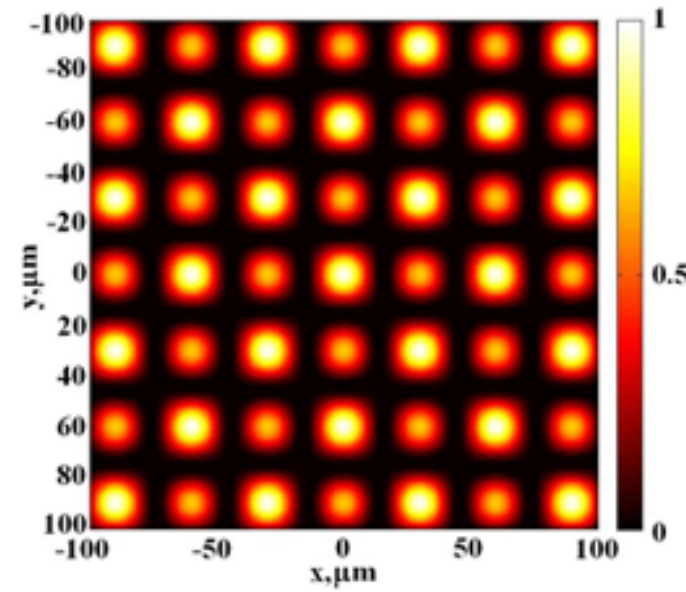

(a)

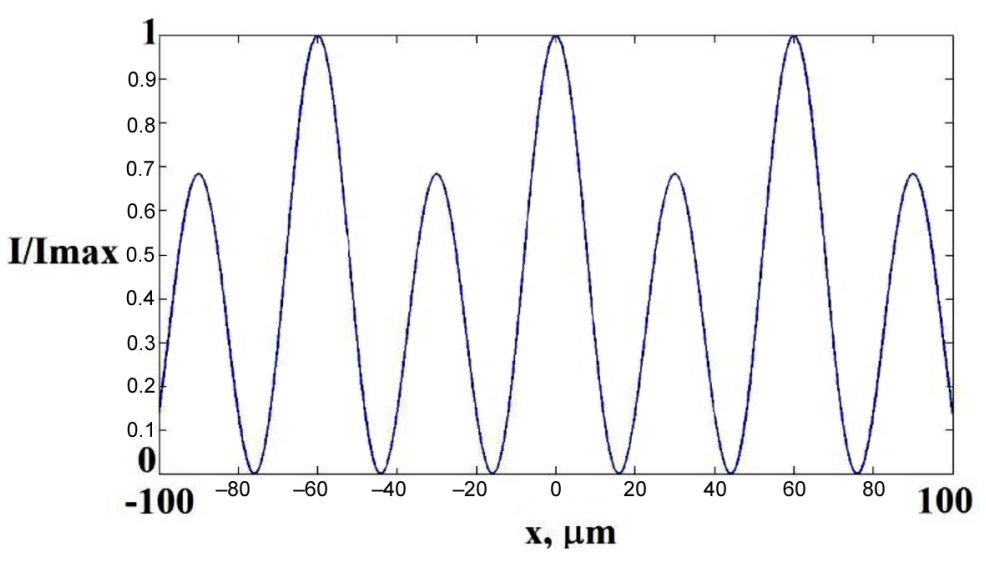

(b)

Fig. 10. Five-beam interference pattern when four beams are identical and the fifth beam in the centre (zero-order) has intensity 7 times lower than that of other four beams: (a) intensity pattern from top, (b) intensity distribution in the cross-section. 


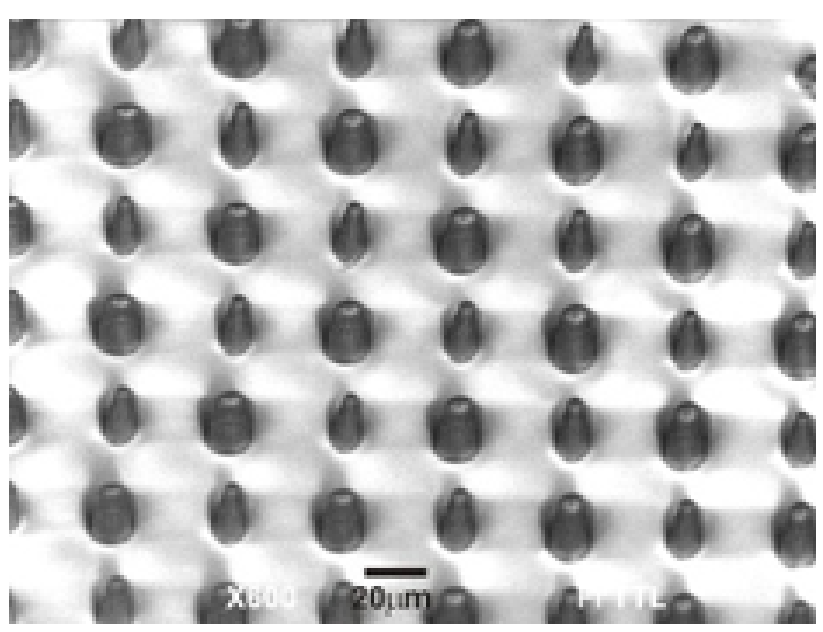

(a)

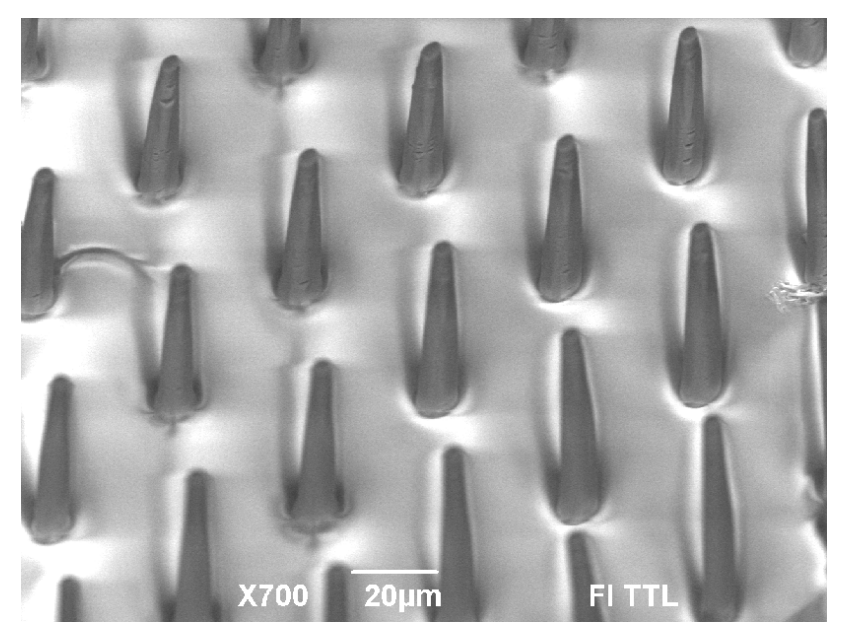

(b)

Fig. 11. Structures fabricated by the five-beam interference pattern when four beams are identical and the fifth beam in the centre (zero order) has intensity 7 times lower than that of other four beams, with the average laser power $\sim 400 \mathrm{~mW}$, repetition rate $5 \mathrm{kHz}$, peak pulse intensity $\sim 0.13 \mathrm{TW} / \mathrm{cm}^{2}$, photo-initiator BIS concentration $2 \%$ by w. t., exposure time $25 \mathrm{~s}$, and wavelength $1030 \mathrm{~nm}$ at different thickness of photopolymer: (a) $25 \mu \mathrm{m}$, (b) $\sim 60 \mu \mathrm{m}$. SEM images of the structures are tilted by $34 \mathrm{deg}$.

and only pillars fabricated using higher intensity remained. In this case the period of the fabricated structure is doubled without any intensity decrease in the beam overlapping area. In the normal way (by changing focal lengths of lenses), the intensity in the beam overlapping area decreases four times by increasing the period twice (by doubling the period). Therefore, the double-period effect can be used especially in the multi-photon polymerization process when high intensities are required.

\section{Conclusions}

The fabrication of various periodic structures by using holographic lithography was demonstrated. Several methods of the holographic lithography technique were reviewed and it has been shown that many factors of the interfering beams such as polarization, the number of interfering beams, phase shift, laser dose, the angle between interfering beams, the wavelength of the used laser have influence on the shape of the fabricated structure. It has been demonstrated that the angle between the interfering beams is responsible for the period. The laser exposure dose and the wavelength are responsible for the width of the pillars. The number of interfering beams is crucial for the shape of the fabricated structure (Fig. 2). By changing the polarization and phase shift, it is possible to form a structure with the $\sqrt{2}$ times reduced period compared to the period of the four interfering beams with the same phase. This structure is also demonstrated in this work. Moreover, we have demonstrated that by adding the fifth beam (zero-order) with a small intensity ( $\sim 7$ times smaller than the intensity in/of the first order beam), the double-period effect in $x$ and $y$ directions is observed. In $z$ direction the period is large $(\sim 3.45 \mathrm{~mm})$ and it is larger than the thickness of the photopolymer, so in fact the 2D structure is formed instead of the $3 \mathrm{D}$ structure. The double effect allows us to double the period without any intensity decrease in the beam overlapping area. In the normal way by using a DOE and lenses, the intensity in the beam overlapping area decreases four times by increasing the period twice (by doubling the period). Therefore, the double-period effect can be used especially in the multi-photon polymerization process when high intensities are required. The fabricated periodic micro-structures have the potential to be used for various applications such as biomedical for the investigation of stem cells behaviour, micro-fluidic for controlling the flow of fluids on a small length scale, or photonics for light localization.

\section{Acknowledgement}

The project VP1-3.1-ŠMM-08-K-01-009 is financially supported by the National Program Improvement 
of the Skills of Researchers under supervision of the Lithuanian Ministry of Education and Science. M. Malinauskas acknowledges the Lithuanian Academy of Sciences for the Young Researcher's Grant.

\section{References}

[1] V. Berger, O. Gauthier-Lafaye, and E. Costard, Photonic band gaps and holography, J. Appl. Phys. 82, 60-64 (1997).

[2] M. Campbell, D.N. Sharp, M.T. Harrison, R.G. Denning, and A.J. Turberfield, Fabrication of photonic crystals for the visible spectrum by holographic lithography, Nature 404, 53-56 (2000).

[3] T. Kondo, S. Matsuo, S. Juodkazis, and H. Misawa, Femtosecond laser interference technique with diffractive beam splitter for fabrication of threedimensional photonic crystals, Appl. Phys. Lett. 79(6), 725-727 (2001).

[4] T. Kondo, S. Juodkazis, V. Mizeikis, S. Matsuo, and H. Misawa, Fabrication of three-dimensional periodic microstructures in photoresist SU- 8 by phase-controlled holographic lithography, New J. Phys. 8(10), 250 (2006).

[5] S. Maruo and K. Ikuta, Three-dimensional microfabrication by use of single-photon-absorbed polymerization, Appl. Phys. Lett. 76(19), 2656-2658 (2000).

[6] S. Maruo, O. Nakamura, and S. Kawata, Threedimensional microfabrication with two-photonabsorbed photopolymerization, Opt. Lett. 22(2), 132-134 (1997).

[7] I. Divliansky, T.S. Mayer, K.S. Holliday, and V.H. Crespi, Fabrication of three-dimensional polymer photonic crystal structures using single diffraction element interference lithography, Appl. Phys. Lett. 82(11), 1667-1669 (2003).

[8] Y. Zhong, L. Wu, H. Su, K.S. Wong, and H. Wang, Fabrication of photonic crystals with tunable surface orientation by holographic lithography, Opt. Express 14(15), 6837-6843 (2006).

[9] Y. Zhong, J. Zhou, and K.S. Wong, Two-photon fabrication of photonic crystals by single-beam laser holographic lithography, J. Appl. Phys. 107(7), 074311 (2010).

[10] K. Ohlinger, F. Torres, Y. Lin, K. Lozano, D. Xu, and K.P. Chen, Photonic crystals with defect structures fabricated through a combination of holographic lithography and two-photon lithography, J. Appl. Phys. 108(7), 073113 (2010).

[11]M. Malinauskas, P. Danilevicius, E. Balciunas, S. Rekstyte, E. Stankevicius, D. Baltriukiene, V. Bukelskiene, G. Raciukaitis, and R. Gadonas, Applications of nonlinear laser nano/microlithography: fabrication from nanophotonic to biomedical components, Proc. SPIE 8204, 820407-11 (2011).
[12]E. Stankevicius, E. Balciunas, M. Malinauskas, G. Raciukaitis, D. Baltriukiene, and V. Bukelskiene, Holographic lithography for biomedical applications, Proc. SPIE 8433, 843312-7 (2012).

[13] M. Malinauskas, A. Zukauskas, G. Bickauskaite, R. Gadonas, and S. Juodkazis, Mechanisms of three-dimensional structuring of photo-polymers by tightly focussed femtosecond laser pulses, Opt. Express 18(10), 10209-10221 (2010).

[14] V. Mizeikis, S. Matsuo, S. Juodkazis, and H. Misawa, Femtosecond laser microfabrication of photonic crystals, in: 3D Laser Microfabrication, eds. H. Misawa and S. Juodkazis (WILEY-VCH, Weinheim, 2006) pp. 239-286.

[15]E. Hecht, Optics (Addison Wesley, San Francisco, 2002).

[16] A.F. Lasagni, D. Yuan, P. Shao, and S. Das, Periodic micropatterning of polyethylene glycol diacrylate hydrogel by laser interference lithography using nano- and femtosecond pulsed lasers, Adv. Eng. Mater. 11(3), B20-B24 (2009).

[17] M. Ellman, A. Rodríguez, N. Pérez, M. Echeverria, Y.K. Verevkin, C.S. Peng, T. Berthou, Z. Wang, S.M. Olaizola, and I. Ayerdi, High-power laser interference lithography process on photoresist: Effect of laser fluence and polarisation, Appl. Surf. Sci. 255(10), 5537-5541 (2009).

[18]H. Misawa, T. Kondo, S. Juodkazis, V. Mizeikis, and S. Matsuo, Holographic lithography of periodic two- and three-dimensional microstructures in photoresist SU-8, Opt. Express 14(17), 7943-7953 (2006).

[19]E. Molotokaite, M. Gedvilas, G. Račiukaitis, and V. Girdauskas, Picosecond laser beam interference ablation of thin metal film on glass substrate, J. Laser Micro/Nanoeng. 5, 74-79 (2010).

[20]J. Li, Y. Liu, X. Xie, P. Zhang, B. Liang, L. Yan, J. Zhou, G. Kurizki, D. Jacobs, K.S. Wong, and Y. Zhong, Fabrication of photonic crystals with functional defects by one-step holographic lithography, Opt. Express 16(17), 12899-12904 (2008).

[21] G.P. Wang, C. Tan, Y. Yi, and H. Shan, Holography for one-step fabrication of three-dimensional metallodielectric photonic crystals with a single continuous wavelength laser beam, J. Mod. Opt. 50(14), 2155-2161 (2003).

[22] A.A. Maznev, T.F. Crimmins, and K.A. Nelson, How to make femtosecond pulses overlap, Opt. Lett. 23(17), 1378-1380 (1998).

[23]S. Juodkazis, V. Mizeikis, and H. Misawa, Threedimensional structuring of resists and resins by direct laser writing and holographic recording, in: Photoresponsive Polymers I, eds. S. Marder and K.-S. Lee (Springer, Berlin, Heidelberg, 2008) pp. 157-206.

[24] Y. Nakata, T. Okada, and M. Maeda, Lines of periodic hole structures produced by laser ablation using interfering femtosecond lasers split by a 
transmission grating, Appl. Phys. A 77(3), 399401 (2003).

[25] A. Ovsianikov, J. Viertl, B. Chichkov, M. Oubaha, B. MacCraith, I. Sakellari, A. Giakoumaki, D. Gray, M. Vamvakaki, M. Farsari, and C. Fotakis, Ultralow shrinkage hybrid photosensitive material for two-photon polymerization microfabrication, ACS Nano 2(11), 2257-2262 (2008).

[26]M. Oubaha, R. Copperwhite, C. Boothman, A. Ovsianikov, R. Kiyan, V. Purlys, M. O’Sullivan, C. McDonagh, B. Chichkov, R. Gadonas, and B. MacCraith, Influence of hybrid organic-inorganic sol-gel matrices on the photophysics of amino-functionalized UV-sensitizers, J. Mater. Sci. 46(2), 400-408 (2011).

[27] E. Stankevicius, T. Gertus, M. Rutkauskas, M. Gedvilas, G. Raciukaitis, R. Gadonas, V. Smilgevicius, and M. Malinauskas, Fabrication of micro-tube arrays in photopolymer SZ2080 by using three different methods of a direct laser polymerization technique, J. Micromech. Microeng. 22(6), 065022 (2012).

[28]E. Stankevicius, M. Malinauskas, M. Gedvilas, B. Voisiat, and G. Raciukaitis, Fabrication of periodic micro-structures by multi-photon polymerization using the femtosecond laser and four-beam interference, Mater. Sci. (Medžiagotyra) 17(3), 244-248 (2011).

[29] M. Malinauskas, G. Bickauskaite, M. Rutkauskas, D. Paipulas, V. Purlys, and R. Gadonas, Selfpolymerization of nano-fibres and nano-membranes induced by two-photon absorption, Lith. J. Phys. 50(1), 135-140 (2010).

[30] S. Wu, J. Serbin, and M. Gu, Two-photon polymerisation for three-dimensional micro-fabrication, J. Photochem. Photobiol. A 181(1), 1-11 (2006).

[31]B. Voisiat, M. Gedvilas, S. Indrisiunas, and G. Raciukaitis, Flexible microstructuring of thin films using multi-beam interference ablation with ultrashort lasers, J. Laser Micro/Nanoeng. 6(3), 185-190 (2011).

[32] K.M. Baker, Highly corrected submicrometer grid patterning on curved surfaces, Appl. Opt. 38(2), 339-351 (1999).

[33]T. Kondo, S. Matsuo, S. Juodkazis, V. Mizeikis, and H. Misawa, Multiphoton fabrication of periodic structures by multibeam interference of femtosecond pulses, Appl. Phys. Lett. 82(17), 2758-2760 (2003).

[34] S. Juodkazis, V. Mizeikis, and H. Misawa, Threedimensional microfabrication of materials by femtosecond lasers for photonics applications, J. Appl. Phys. 106(5), 051101-14 (2009).

\title{
PERIODINIŲ MIKRODARINIŲ FORMAVIMAS HOLOGRAFINĖS LITOGRAFIJOS BŪDU
}

\author{
E. Stankevičius ${ }^{\text {a }}$, M. Gedvilas ${ }^{\text {a }}$, B. Voisiat ${ }^{\text {a }}$, M. Malinauskas ${ }^{\text {b }}$, G. Račiukaitis a \\ a Fiziniu ir technologijos mokslu centras, Vilnius, Lietuva \\ ${ }^{\mathrm{b}}$ Vilniaus universiteto Lazeriniu tyrimu centras, Vilnius, Lietuva
}

\begin{abstract}
Santrauka
Straipsnyje apžvelgiami holografinès litografijos principai ir demonstruojamos holografinès litografijos galimybès suformuoti ịvairaus periodo mikrodarinius SZ2080 fotopolimere. Taip pat aptariama ịvairių lazerinio proceso parametrų - ekspozicijos trukmès, interferuojančių pluoštų bangos ilgio, fazès poslinkio tarp interferuojančių pluoštų - ịtaka formuojamiems dariniams ir pademonstruotas dvigubo periodo efektas. Šis efektas atsiranda, kai prie keturių identiškų pirmo difrakcinio maksimumo pluoštų yra pridedamas mažo intensyvumo centrinis pluoštas ( 7 kartus mažesnis už pirmo difrakcinio maksimumo pluoštą), tuomet suformuoto periodinio mikrodarinio kas ant-
\end{abstract}

ras stulpelis yra plonesnis už šalia esantị stulpelị. Formuojant pakankamai aukštus mikrodarinius $(\sim 60 \mu \mathrm{m})$ plonesni stulpeliai ryškinimo proceso metu sugriūna ir yra išplaunami, lieka tik storesni stulpeliai. Tokiu būdu galima padvigubinti formuojamo mikrodarinio periodą nemažinant intensyvumo pluoštų persiklojimo zonoje. Šis efektas gali būti labai naudingas daugiafotoniškai formuojant didelio periodo struktūras.

Holografinès litografijos būdu suformuoti periodiniai mikrodariniai gali būti panaudoti biomedicinoje kaip karkasai kamieninèms ląstelèms auginti, mikrofluidikoje - kontroliuoti skysčiu ar dujų tekẻjimą. 